\title{
STUDIES ON PHYTOCHEMICAL SCREENING, TANNINS CONTENT AND ANTIBACTERIAL ACTIVITY FROM LEAF AND CALLUS EXTRACTS OF MEMECYLON UMBELLATUM
}

\author{
ANBUKKARASI $\mathbf{M}^{1}$, DHAMOTHARAN $\mathbf{R}^{2}$, JANARTHANAM B ${ }^{3 *}$ \\ ${ }^{1}$ Department of Botany, Quaid-e-Millath Government College for Women, Chennai, Tamil Nadu, India. ${ }^{2}$ Department of Botany, Presidency \\ College, Chennai, Tamil Nadu, India. ${ }^{3}$ Plant Biotechnology Division, Poonga Biotech Research Centre, Choolaimedu, Chennai, Tamil Nadu, \\ India. Email: Kb_janarthanan@yahoo.com
}

Received: 15 September 2016, Revised and Accepted: 24 February 2017

ABSTRACT

Objective: This study aims to determine the phytochemical screening, tannins content, and antibacterial activity from leaf and callus extracts of Memecylon umbellatum.

Methods: Preliminary screening involved the qualitative methods to detect the presence of terpenoids, flavonoids, phenols, tannins, steroids, quinones, saponins, cardiac glycosides, and alkaloids. Total tannins contents were quantitatively estimated with tannic acid as standard. Different concentrations of ethanolic leaf and callus extracts were tested using the agar disc diffusion technique for the antibacterial activity against Bacillus subtilis, Bacillus cereus, Staphylococcus aureus, Pseudomonas aeruginosa, and Escherichia coli.

Results: The phytochemical analysis of leaf and callus extract of M. umbellatum revealed the presence of significant secondary metabolites such as tannins, saponins, quinones, cardiac glycosides, phenols, flavonoids, terpenoids, steroids, and alkaloids. The total tannins content in callus and leaf extract were found to be $11.37 \mathrm{mg}$ tannic acid equivalents (TAE)/g and $7.1 \mathrm{mg}$ TAE/g, respectively. The antibacterial activity of ethanolic leaf and callus extracts of M. umbellatum shown more active against $B$. subtilis. Both the callus and leaf extract of $M$. umbellatum was found to be inactive against E. coli.

Conclusion: It was concluded that the powerful antibacterial effect is attributed to the greater amount of tannin compounds in the ethanolic callus extracts of M. umbellatum.

Keywords: Memecylon umbellatum, Callus extract, Tannins, Phytochemical analysis, Disc diffusion, Antibacterial activity.

(C) 2017 The Authors. Published by Innovare Academic Sciences Pvt Ltd. This is an open access article under the CC BY license (http://creativecommons. org/licenses/by/4. 0/) DOI: http://dx.doi.org/10.22159/ajpcr.2017.v10i5.15198

\section{INTRODUCTION}

Plants are the richest resource of drugs of traditional systems of medicine, modern medicines, nutraceuticals, food supplements, folk medicines, pharmaceutical intermediates, and chemical entities for synthetic drugs [1]. Most of the people in rural and urban areas of the world are dependent on the medicinal plants for the treatment of infectious diseases. The Ayurvedic and Unani systems of medicines are widely used by the people of Indian subcontinent. In spite of the recent domination of the synthetic chemistry as a method to discover and produce drugs, the potential of bioactive plants or their extracts to provide new and novel products for disease treatment and prevention is still enormous [2]. Plant-derived medicines are relatively safer than synthetic alternatives, offering profound therapeutic benefits and more affordable treatment. Dietary phytochemicals are considered as an effective tool to cure body disorder. They play important roles as therapeutic agents in the prevention of many diseases [3]. Among the different plant derivatives, secondary metabolites have been proven to be the most important group of compounds that showed a wide range of antibacterial and antifungal activity $[4,5]$.

Tannins have high polyphenolic compounds present in plants, foods and beverages, soluble in water and polar organic solvents. These tannins are classified as hydrolysable and condensed tannins based on their chemical structure and biological activity [6,7]. Both types of tannins are capable of forming strong complexes with certain type of proteins depressing the rate of their digestion [8]. Tannins may also bind to bacterial enzymes or form indigestible complexes with cell wall carbohydrates reducing the cell wall digestibility $[9,11]$. In recent years, tannins have been investigated to possess high antioxidants [12], free radical scavenging activity [13], antimicrobial [14], gastroprotective, and antiulcerogenic activities [15]. Moreover, tannins have been investigated as potent inhibitors of lipid peroxidation in heart mitochondria [16] and possess anti-fibrotic effects [17]. Due to these therapeutic properties tannins can be used in the treatment of various diseases to improve human health.

Memecylon umbellatum (Melastomataceae) is an erect tree, herb or shrub, sometimes climbers commonly known as "Kasan" distributed throughout western peninsula, the eastern and southern parts of India and in the Andaman islands [18]. The leaf powder has antidiabetic potential and also used to treat eye troubles, gonorrhea, leukorrhea, wounds, skin diseases, and antioxidant property $[19,20]$. Plant contains a wide variety of phytoconstituents such as umbellactone, $\beta$-amyrin, Oleanolic acid, ursolic acid, sitosterol, and organic acids. Hence, in this study, the leaf and callus of M. umbellatum were screened for phytochemical constituents, tannins content and the antibacterial activity against various human pathogens.

\section{MATERIALS AND METHODS}

Collection of plant material

The healthy plants of M. umbellatum leaf (Fig. 1) were collected from Panruti area, Cuddalore District, Tamil Nadu. The collected leaves were brought to the laboratory and maintained at Poonga Biotech Research Centre, Plant Biotechnology Division, Chennai - 600 094, Tamil Nadu, India.

Preparation of the plant extract $[21,22]$

The dried leaf and callus ( $1 \mathrm{~g}$ each) of M. umbellatum collected and powdered finely with pestle and mortar and extracted with $15 \mathrm{ml}$ 
aqueous, ethanol, chloroform, acetone, and petroleum ether for 1 minute using an Ultra Turax mixer $(13,000$ RPM) and soaked overnight at room temperature. The sample was then filtered through Whatman No. 1 paper in a Buchner funnel. The filtered solution was evaporated under vacuum in a rotavator at $40^{\circ} \mathrm{C}$ to a constant weight and then dissolved in respective solvents. The concentrated extracts were stored in airtight container in refrigerator below $10^{\circ} \mathrm{C}$.

\section{Phytochemical screening from leaf and callus extract of} M. umbellatum

The phytochemical screening of leaf and callus extracts of M. umbellatum was assessed by standard method [23-25]. Phytochemical screening was carried out on the leaf and callus extracts using different solvents to identify the major natural chemical groups such as tannins, saponins, flavonoids, phenols, terpenoids, alkaloids, glycosides, cardiac glycosides, coumarins, and steroids. General reactions in this analysis revealed the presence or absence of these compounds in the leaf and callus extracts tested.

\section{Estimation of tannins from leaf and callus extract of $M$. umbellatum} Tannins content from leaf and callus extract of M. umbellatum was estimated according to the method as described by Fagbemi et al. [26]. The ethanolic extract $(1 \mathrm{ml})$ was mixed with Folin-Ciocalteu reagent $(0.5 \mathrm{ml})$, followed by the addition of saturated sodium carbonate $\left(\mathrm{Na}_{2} \mathrm{CO}_{3}\right)$ solution $(1 \mathrm{ml})$ and distilled water $(8 \mathrm{ml})$. The reaction mixture was allowed to stand for 30 minutes at room temperature. The supernatant was obtained by centrifugation and absorbance was recorded at $725 \mathrm{~nm}$ using ultraviolet-visible spectrophotometer. Increasing concentrations of standard tannic acid were prepared, and the absorbance of various tannic acid concentrations was plotted for a standard graph. The tannin content was expressed as mg tannic acid equivalent (TAE)/g of the sample.

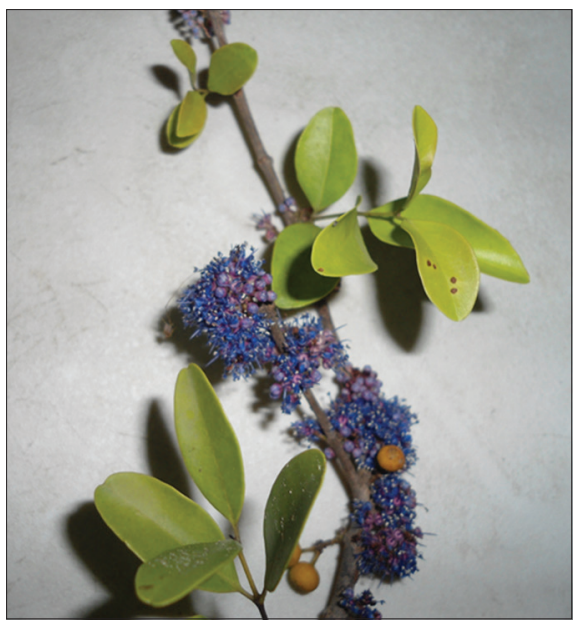

Fig. 1: Mother plants of Memecylon umbellatum (Panruti area)
Antibacterial activity of leaf and callus extract of $M$. umbellatum The ethanolic leaf and flower extracts of M. umbellatum plant were used for antibacterial study [27,28]. Different concentrations $(10,20$ and $30 \mathrm{mg} / \mathrm{ml})$ of the concentrated ethanolic leaf and callus extract were tested for its antimicrobial activity against pathogenic bacterial strains such as Bacillus subtilis, Staphylococcus aureus, Bacillus cereus, Escherichia coli, and Pseudomonas aeruginosa. The bacterial cultures were grown in Muller-Hinton Agar and Muller-Hinton Broth (Himedia) [29].

\section{Antibacterial activity assays}

Antibacterial activity was measured using the standard method of diffusion disc plates on agar [30]. For antimicrobial assay, all bacterial strains were grown in Mueller-Hinton Broth Medium (Himedia) for $24 \mathrm{hrs}$ at $37^{\circ} \mathrm{C}$ and plated on Mueller-Hinton Agar (Himedia) for agar diffusion experiments. Then, $0.1 \mathrm{ml}$ of each culture of bacteria was spread on agar plate surfaces. Sterile disc (Hi Media, $6 \mathrm{~mm}$ in diameter) was placed on the agar medium to load $20 \mathrm{ml}$ of different concentration $(10-30 \mathrm{mg} / \mathrm{ml})$ of ethanolic leaf and callus extracts of M. umbellatum were tested. Inhibition diameters were measured after incubation for $24 \mathrm{hrs}$ at $37^{\circ} \mathrm{C}$. Blanks of solvent only (processed in the same way) were also tested for antibacterial activity.

\section{RESULTS AND DISCUSSION}

In this study, phytochemical screening was performed with aqueous, ethanol, chloroform, acetone and petroleum ether of the leaf and callus extracts of M. umbellatum. The phytochemical screening of five different extracts studied showed that the ethanolic extract of leaf and callus of M. umbellatum were rich in phenols, tannins, saponins, flavonoids, alkaloids and steroids, followed by aqueous and acetone extracts (Tables 1 and 2). Phytochemical constituents such as tannins, flavonoids, alkaloids, and several other aromatic compounds are secondary metabolites of plants that serve as defense mechanism against predation by many micro-organisms, insects and herbivores. The curative properties of medicinal plants are perhaps due to the presence of various secondary metabolites such as alkaloids, flavonoids, phenols, saponins, and steroids. [31]. Tannin compounds present in many medicinal plants inhibit the growth of many fungi, yeasts, bacteria, and viruses [32]. The presence of alkaloids and saponins in leaf extract, the biological function of alkaloids and their derivatives are very important and are used in analgesic, antispasmodic and bactericidal activities [33]. Saponins have properties of precipitating and coagulating red blood cells, and they also have cholesterol binding properties, formation of foams in aqueous solutions and hemolytic activity [34] and traditionally saponins have been extensively used as detergents, as pesticides and molluscicides, in addition to their industrial applications as foaming and surface active agents they also have beneficial health effects [35]. Plant steroids are known to be important for their cardiotonic activities and also used in nutrition, herbal medicine, and cosmetics. Thus, the preliminary screening tests may be useful in the detection of the bioactive principles, leading to drug discovery and development [36]. Further, these tests facilitate their

Table 1: Phytochemical screening from leaf extracts of $M$. umbellatum

\begin{tabular}{|c|c|c|c|c|c|}
\hline \multirow[t]{2}{*}{ Phytochemicals } & \multicolumn{5}{|c|}{ Leaf extract of $M$. umbellatum } \\
\hline & Ethanol & Aqueous & Acetone & Chloroform & Petroleum ether \\
\hline Tannins & ++ & + & + & + & + \\
\hline Saponins & ++ & + & - & - & - \\
\hline Quinones & + & - & - & - & - \\
\hline Flavonoids & ++ & + & - & - & - \\
\hline Phenol & + & + & + & + & + \\
\hline Glycosides & - & - & - & - & - \\
\hline Cardiac glycosides & ++ & + & + & - & + \\
\hline Terpenoids & + & + & - & - & - \\
\hline Steroids & + & + & - & - & - \\
\hline Alkaloids & + & - & - & - & - \\
\hline
\end{tabular}

++: Strong positive, +: Positive; -: Negative, M. umbellatum: Memecylon umbellatum 
Table 2: Phytochemical screening from callus extracts of $M$. umbellatum

\begin{tabular}{|c|c|c|c|c|c|}
\hline \multirow[t]{2}{*}{ Phytochemicals } & \multicolumn{5}{|c|}{ Callus extract of $M$. umbellatum } \\
\hline & Ethanol & Aqueous & Acetone & Chloroform & Petroleum ether \\
\hline Tannins & ++ & + & + & + & + \\
\hline Quinones & + & - & - & - & - \\
\hline Flavonoids & ++ & + & - & - & - \\
\hline Phenol & ++ & + & + & + & + \\
\hline Glycosides & - & - & - & - & - \\
\hline Cardiac glycosides & ++ & + & - & + & - \\
\hline Terpenoids & + & + & + & - & + \\
\hline Steroids & ++ & + & - & - & - \\
\hline Alkaloids & ++ & + & + & - & - \\
\hline
\end{tabular}

++: Strong positive, +: Positive, -: Negative, M. umbellatum: Memecylon umbellatum

Table 3: Quantitative estimation of tannin content from leaf and callus extract of $M$. umbellatum

\begin{tabular}{ll}
\hline Extract of $\boldsymbol{M}$. umbellatum & $\begin{array}{l}\text { Tannin content (mg TAE/g dry } \\
\text { material) }\end{array}$ \\
\hline Leaf extract & $7.1 \mathrm{mg}$ \\
Callus extract & $11.37 \mathrm{mg}$ \\
\hline
\end{tabular}

M. umbellatum: Memecylon umbellatum, TAE: Tannic acid equivalent

Table 4: Antibacterial activity of leaf and callus extract of M. umbellatum

\begin{tabular}{|c|c|c|c|}
\hline \multicolumn{4}{|c|}{ Inhibition zone in diameter $(\mathrm{mm})^{*}$} \\
\hline \multirow{2}{*}{$\begin{array}{l}\text { Micro-organisms } \\
\text { tested }\end{array}$} & \multicolumn{3}{|c|}{ Concentrations of extract } \\
\hline & $10 \mathrm{mg} / \mathrm{ml}$ & $20 \mathrm{mg} / \mathrm{ml}$ & $30 \mathrm{mg} / \mathrm{ml}$ \\
\hline \multicolumn{4}{|l|}{ Ethanolic leaf extract } \\
\hline B. subtilis• & - & 9 & 13 \\
\hline B. сеreus• & - & - & 11 \\
\hline P. aeruginosa $\bullet$ & - & - & 9 \\
\hline S. aureus $\bullet$ & - & - & 8 \\
\hline E. coli $\bullet$ & - & - & - \\
\hline \multicolumn{4}{|c|}{ Ethanolic callus extract } \\
\hline B. subtilis• & - & 12 & 15 \\
\hline B. сеreus• & - & 11 & 14 \\
\hline P. aeruginosa $\bullet$ & - & 12 & 12 \\
\hline S. aureus $\bullet$ & - & 10 & 12 \\
\hline E. coli• & - & - & - \\
\hline
\end{tabular}

-This strain was obtained from MTCC, ${ }^{*}$ includes diameter of disc $(6 \mathrm{~mm})$; average three replicates, B. subtilis: Bacillus subtilis, B. cereus: Bacillus cereus,

S. aureus: Staphylococcus aureus, P. aeruginosa: Pseudomonas aeruginosa

quantitative estimation and qualitative separation of pharmacologically active chemical compounds.

The result of this study recorded highest tannins content in the callus extract of M. umbellatum and the tannins content was expressed as mg TAE per gram of the sample. The optimum yield of tannins was found to be $11.37 \mathrm{mg}$ TAE/g dry weight from callus followed by $7.1 \mathrm{mg}$ TAE/g dry weight from leaf of $M$. umbellatum (Table 3). The effect of ethanol on the extraction of tannins from M. umbellatum callus extracts was good followed by leaf extract. The results corroborate with the findings of Singh et al. [37] who have reported the maximum yield of tannins from the ethanolic extract of Artemisia absinthium. Tannins are the natural polyphenolic compounds which can influence the nutritive value of different food stuffs utilized by human and other animals they also have large influence on the phytochemical and phytotherapeutic value of medicinal plants. Various methods have been used to increase the extraction efficiency of tannins from different medicinal plants for their use in pharmaceutical field [38]. Ethanol has been found to be the most commonly used solvent for the extraction of tannins rather than other
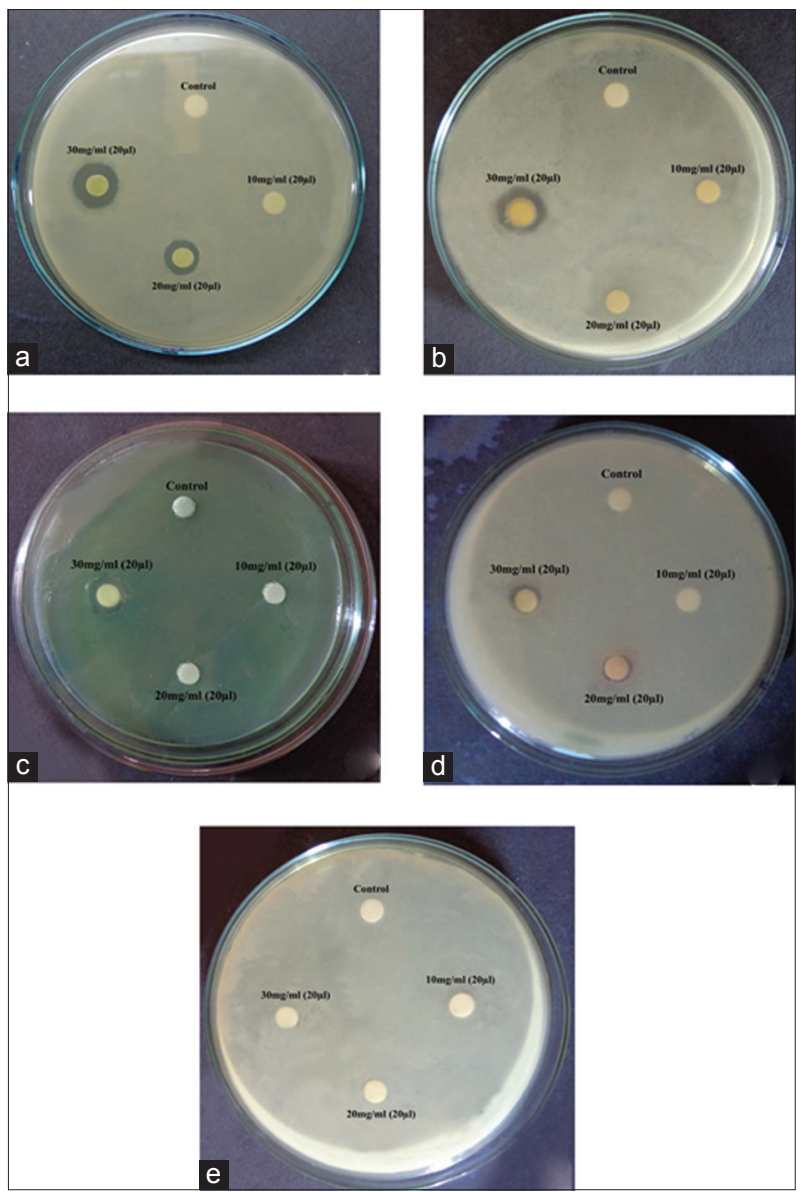

Fig. 2: Antibacterial activity of ethanolic leaf extract of Memecylon umbellatum, antibacterial activity of leaf extract of Memecylon umbellatum against Bacillus subtilis (a), Bacillus cereus (b), Pseudomonas aeruginosa (c), Staphylococcus aureus (d), and Escherichia coli (e)

organic solvents [39]. Tannins have stringent properties, hasten the healing of wounds and inflamed mucous membranes [40].

The data presented in Table 4, indicate that the leaf and callus extracts of M. umbellatum inhibit the growth of some micro-organism to various concentration. The concentrations of $10-30 \mathrm{mg} / \mathrm{ml}$ ethanolic extract showed antimicrobial activity against $S$. aureus, B. cereus, B. subtilis, P. aeruginosa, and inactivity against E. coli (Figs. 2 and 3). The maximum clear zone of inhibition was found at $30 \mathrm{mg} / \mathrm{ml}$ of $75 \%$ ethanolic callus extract of M. umbellatum than leaf extract. In both the case of leaf and callus extracts, no zone of inhibition was found in lower 

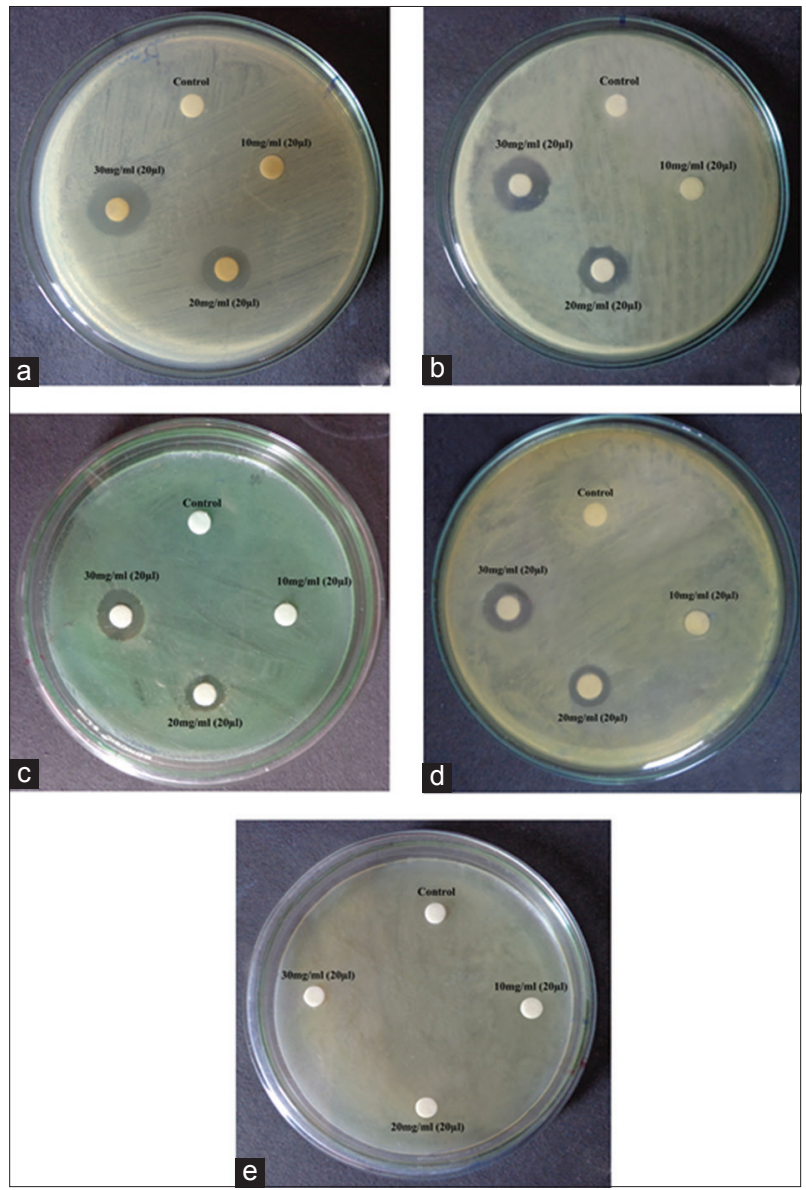

Fig. 3: Antibacterial activity of ethanolic callus extract of Memecylon umbellatum, antibacterial activity of callus extract of Memecylon umbellatum against Bacillus subtilis (a), Bacillus cereus (b), Pseudomonas aeruginosa (c), Staphylococcus aureus (d), and Escherichia coli (e)

concentration $(10 \mathrm{mg} / \mathrm{ml})$. Similar results were obtained on ethanol extracts from leaves of Sida acuta and Acalypha wilkesiana which exhibited antibacterial activity [41,42]. The antimicrobial activities of ethanol extract may be due to the presence of tannins, triterpenoids, and flavonoids. Tannins have been known to form irreversible complexes with proline-rich protein resulting in the inhibition of cell wall synthesis [43]. Thus from our findings, it is concluded that the $75 \%$ ethanolic extracts from dry powdered callus of M. umbellatum have a superior level of antimicrobial activity. The powerful antibacterial effect is attributed to the greater amount of tannins compound in the ethanolic callus extracts of M. umbellatum.

\section{REFERENCES}

1. Hammer KA, Carson CF, Riley TV. Antimicrobial activity of essential oils and other plant extracts. J Appl Microbiol 1999;86(6):985-90.

2. Raskin I, Ribnicky DM, Komarnytsky S, Ilic N, Poulev A, Borisjuk N, et al. Plants and human health in the twenty-first century. Trends Biotechnol 2002;20(12):522-31.

3. Kareem KT, Kareem SO, Adeyemo OJ, Egberongbe RK. In vitro antimicrobial properties of Bridelia ferruginea on some clinical isolates. Agric Biol J N Am 2010;1(3):416-20.

4. Ahmed AM, Rahman MS, Anwar MN. Antimicrobial activity of extracts and crude alkaloids of Polyalthia longifolia (Sonn.). Chittagong Univ J Sci 1999;23(1):53-6.

5. Rahman MS, Anwar MN, Chowdhury AZ. Antibacterial activity of secondary metabolites from Holarrhena antidysenterica stem bark. Bangladesh J Microbiol 1999;16(2):101-5.

6. Haslam E. Natural polyphenols (vegetable tannins) as drugs: Possible modes of action. J Nat Prod 1996;59(2):205-15.
7. Makkar HP, Becker K. Do tannins in leaves of trees and shrubs from African and Himalayan regions differ in level and activity? Agroforestry Syst 1998;40:59-68.

8. Feeny P. Seasonal changes in oak leaf tannins and nutrients as a cause of spring feeding by winter moth caterpillars. Ecology 1970;51:565-81.

9. Barry TN, Manley RT. The role of condensed tannins in the nutritional value of Lotus pedunculatus for sheep. 2. Quantitative digestion of carbohydrates and proteins. Br J Nutr 1984;51(3):493-504.

10. Barry TN, Manley TR, Duncan SJ. The role of condensed tannins in the nutritional value Lotus pedunculatus for sheep. 4. Sites of carbohydrate and protein digestion as influenced by dietary reactive tannin concentration. Br J Nutr 1986;55:123-37.

11. Reed JD, Soller H, Woodward A. Fodder tree and straw diets for sheep: Intake, growth, digestibility and the effects of phenolics on nitrogen utilisation. Amim Feed Sci Technol 1990;30(1-2):39-50.

12. Amarowicz R, Troszyńska A, Baryłko-Pikielna N, Shahiid F. Polyphenolics extracts from legume seeds: Correlation between total antioxidant activity, total phenolics content, tannins content and astringency. J Food Lipids 2004;11:278-86.

13. Koleckar V, Kubikova K, Rehakova Z, Kuca K, Jun D, Jahodar L, et al. Con-densed and hydrolysable tannins as antioxi-dants influencing the health. Mini Rev Med Chem 2008;8(5):436-47.

14. Ho PL, Yung RW, Tsang DN, Que TL, Ho M, Seto WH, et al. Increasing resistance of Streptococcus pneumoniae to fluoroquinolones: Results of a Hong Kong multicentre study in 2000. J Antimicrob Chemother 2001;48:659-65.

15. Ramirez RO, Roa CC Jr. The gastroprotective effect of tannins extracted from duhat (Syzygium cumini Skeels) bark on $\mathrm{HCl} /$ ethanol induced gastric mucosal injury in Sprague-Dawley rats. Clin Hemorheol Microcirc 2003;29(3-4):253-61.

16. Hong CY, Wang CP, Huang SS, Hsu FL. The inhibitory effect of tannins on lipid peroxidation of rat heart mitochondria. J Pharm Pharmacol 1995;47(2):138-42.

17. Chuang HY, Ng LT, Lin LT, Chang JS, Chen JY, Lin TC, et al. Hydrolysable tannins of tropical almond show antifibrotic effects in TGF-B1-induced hepatic stellate cells. J Sci Food Agric 2011;91(15):2777-84.

18. Joshi H, Gururaja M, Singh S. Memecylon umbellatum (Melastomataceae): A Review. Int J Pharm Sci Rev Res 2011;11(2):54-8.

19. Ayyanar MK, Ignacimuthu SS. Traditional herbal medicines used for the treatment of diabetes among two major tribal groups in south Tamil Nadu, India. Ethnobot Leafl 2008;12:276-80.

20. Karuppusamy S. Medicinal plants used by Paliyan tribes of Sirumalai hills of Southern India. Nat Prod Radiance 2007;6(5):436-42.

21. Pizzale L, Bortolomeazzi R, Vichi S, Conte LS. Antioxidant activity of sage and oregano extracts related to their phenolic compound content. J Sci Food Agric 2002;82:1645-51.

22. Lu Y, Foo Y. Antioxidant activities of polyphenols from sage (Salvia officinalis). Food Chem 2001;75:197-202.

23. Brinda P, Sasikala P, Purushothaman KK. Pharmacognostic studies of Merugan kizhangu. Bull Med Eth Bot Res 1981;3:84-96.

24. Siddiqui AA, Ali M. Practical Pharmaceutical Chemistry. $1^{\text {st }}$ ed. New Delhi: CBS Publisher and Distributors; 1997. p. 126-31.

25. Savithramma N, Linga RM, Bhumi G. Phytochemical screening of Thespesia populnea (L.) Soland and Tridax procumbens L. J Chem Pharm Res 2011;3(5):28-34.

26. Fagbemi TN, Oshodi AA, Ipinmoroti KO. Processing effects on some antinutritional factors and in vitro multienzyme protein digestibility (IVPD) of three tropical seeds: Breadnut (Artocarpus altilis), cashewnut (Anacardium occidentale) and fluted pumpkin (Telfairia occidentalis). Pak J Nutr 2005;4(4):250-6.

27. Ozkan G, Sagdic O, Baydar NG, Baydar H. Antioxidant and antibacterial activities of Rosa damascena flower extracts. Food Sci Technol Int 2004;10(4):277-81.

28. Janarthanam B, Sumathi E. Antimicrobial activity of Gymnema sylvestre leaf and callus extracts. J Trop Med Plants 2010;11(2):143-7.

29. Lopez A, Hudson JP, Towers GH. Antiviral and antimicrobial activities of Colombian medicinal plants. J Enthopharmacol 2001;77:189-96.

30. Erturk O, Kati H, Yayli N, Demürbaú Z. Antimicrobial properties of Silene multifida (Adams) Rohrb. Plant extracts. Turk J Biol 2006;30:17-21

31. Britto JD, Sebastian SR. Biosynthesis of silver nano particles and its antibacterial activity against human pathogens. Int J Pharm Pharm Sci 2011:5:257-9.

32. Chung KT, Wong TY, Wei CI, Huang YW, Lin Y. Tannins and human health: A review. Crit Rev Food Sci Nutr 1998;38(6):421-64.

33. Stary F. The Natrural Guide to Medicinal Herbs, and Plants. London: 
Tiger Books International; 1998. p. 12-6.

34. Sodipo OA, Akiniyi JA, Ogunbamosu JU. Studies on certain characteristics of extracts of bark of Pansinystalia macruceras (K schemp) pierre exbeille. Glob J Pure Appl Sci 2000;6:83-7.

35. Shi J, Kakuda Y, Yeung D. Antioxidative properties of lycopene and other carotenoids from tomatoes: Synergistic effects. Biofactors 2004;21(1-4):203-10.

36. Doss A, Mubarak HM, Dhanabalan R. Antibacterial activity of tannins from the leaves of Solanum trilobatum Linn. Indian J Sci Technol 2009;2(2):41-3.

37. Singh R, Kumar P, Singh VG. Total phenolic, flavonoids and tannin contents in different extracts of Artemisia absinthium. J Intercult Ethnopharmacol 2012;1(2):101-4.

38. Cobzac S, Moldovan M, Olah NK, Bobos L, Surducan E. Tannin extraction efficiency, from Rubus idaeus, Cydonia oblonga and Rumex acetosa using different extraction techniques and spectro-photometric quantification. Acta Univ Cibiniensis Ser F Chem 2005;8(2):55-9.
39. Doshi H, Satodiya H, Thakur MH, Parabia F, Khan A. Phytochemical screening and biological activity of Calotropis procera (Ait). R. Br. Asclepiadaceae) against selected bacteria and Anopheles stephensi Larvae. Int J Plant Res 2011;1(1):29-33.

40. Salah N, Miller NJ, Paganga G, Tijburg L, Bolwell GP, Rice-Evans C. Polyphenolic flavanols as scavengers of aqueous phase radicals and as chain-breaking antioxidants. Arch Biochem Biophys 1995;322(2):339-46.

41. Oboh IE, Akerele JO, Obasuyi O. Antimicrobial activity of the ethanol extract of the aerial parts of Sida acuta Burm. F. (Malvaceae). Trop J Pharm Res 2007;6(4):809-13.

42. Gotep JG, Agada GO, Gbise DS, Chollom S. Antibacterial activity of ethanolic extract of Acalypha wilkesiana Leaves growing in Jos, Plateau State, Nigeria. Malays J Microbiol 2010;6(2):69-74.

43. Mamtha B, Kavitha K, Srinivasan KK, Shivananda PG. An in vitro study of the effect of Centella asiatica [Indian pennywort] on enteric pathogens. Indian J Pharmacol 2004;36(1):41-4. 